\title{
KNOWLEDGE ON RISK FACTORS FOR TYPE 2 DIABETES MELLITUS AMONG SECONDARY SCHOOL STUDENTS
}

\author{
Aleksandra Góra ${ }^{1}$ Elżbieta Szczepańska ${ }^{1}$, Karolina Janion ${ }^{2}$ \\ ${ }^{1}$ Department of Human Nutrition, School of Health Sciences in Bytom, Medical University of Silesia \\ in Katowice, Poland \\ ${ }^{2}$ Department of Metabolic Disease Prevention, School of Health Sciences in Bytom, Medical University \\ of Silesia in Katowice, Poland
}

\begin{abstract}
Background. Diabetes is a set of metabolic diseases characterized by hyperglycemia caused by improper action and/ or secretion of insulin. Currently, diabetes is becoming a serious challenge in modern medicine, this disease affects 425 million people, and the forecasts indicate that by 2045 the number of cases will increase to 629 million.

Objective. The aim of the study was to evaluate the knowledge about risk factors for type 2 diabetes among secondary school students in the Silesian Province in Poland and to determine whether there are differences between the level of knowledge between girls and boys and between first-, second- and third-grade students.

Material and methods. The survey was conducted among 650 high school students. The research tool was the author's questionnaire. The obtained results were developed using Microsoft Excel 2010 and Statistica 13.3 (TIBCO Inc.).

Results. The definitions of type 2 diabetes were known to $63.9 \% .91 .8 \%$ of high school students indicated excessive body mass as a risk factor for morbidity, while $18.8 \%$ of people indicated the appropriate type of obesity increasing the risk of type 2 diabetes. Most of the students considered abnormal eating habits as an important factor increasing the occurrence of the disease (92.4\%). The most numerous group of high school students were people with average level of knowledge $(89.6 \%)$.

Conclusions. The knowledge of high school students about risk factors for type 2 diabetes was varied. The most numerous group were high school students characterised by the average level of knowledge. There were no statistically significant differences between the proportion of correctly provided responses by women and men. There were statistically significant differences between the proportion of correctly provided responses by first-, second- and third-graders. Our research shows that educational activities should be undertaken, especially about modifiable risk factors for type 2 diabetes.
\end{abstract}

Key words: knowledge, high school students, type 2 diabetes mellitus, risk factors

\section{STRESZCZENIE}

Wprowadzenie. Cukrzyca stanowi zespół chorób metabolicznych, charakteryzujący się hiperglikemią spowodowaną nieprawidłowym działaniem i/lub wydzielaniem insuliny. Obecnie cukrzyca staje się poważnym wyzwaniem współczesnej medycyny, choroba ta dotyka 425 milionów osób, a prognozy stanowią, że do 2045 roku liczba zachorowań wzrośnie do 629 milionów.

Cel badań. Ocena wiedzy uczniów szkół licealnych w Polsce na temat czynników ryzyka zachorowalności na cukrzycę typu 2 oraz stwierdzenie czy istnieją różnice między poziomem wiedzy dziewcząt i chłopców oraz pierwszo-, drugoi trzecioklasistów.

Materiał i metody. Badanie zostało przeprowadzone wśród 650 licealistów. Narzędzie badawcze stanowił autorski kwestionariusz ankiety. Uzyskane wyniki opracowano z wykorzystaniem Microsoft Excel 2010 oraz Statistica 13.3 (TIBCO Inc.).

Wyniki. Definicję cukrzycy typu 2 znało 63,9\% uczniów. 91,8\% licealistów wskazało nadmierną masę ciała jako czynnik ryzyka zachorowalności, natomiast 18,8\% osób wskazało odpowiedni typ otyłości zwiększający ryzyko cukrzycy typu 2. Większość uczniów uznało nieprawidłowe nawyki żywieniowe jako istotny czynnik sprzyjający występowaniu choroby (92,4\%). Najliczniejszą grupę badanych stanowiły osoby charakteryzujące się średnim poziomem wiedzy $(89,6 \%)$.

Wnioski. Wiedza badanych uczniów na temat czynników ryzyka zachorowalności na cukrzycę typu 2 była zróżnicowana. Najliczniejszą grupę stanowili licealiści charakteryzujący się średnim poziomem wiedzy. Nie stwierdzono występowania istotnych statystycznie różnic między odsetkiem prawidłowo udzielonych odpowiedzi przez dziewczęta i chłopców. Stwierdzono występowanie istotnych statystycznie różnic między odsetkiem prawidłowo udzielonych odpowiedzi przez

Corresponding author: Elżbieta Szczepańska, Department of Human Nutrition, School of Health Sciences in Bytom, Medical University of Silesia in Katowice, Jordana Street 19, 41-808 Zabrze, Poland, tel. +48 32275 51 97, e-mail: eszczepanska@sum.edu.pl 
pierwszo-, drugo- i trzecioklasistów. Z przeprowadzonych badań wynika, że należy podejmować działania edukacyjne, ze szczególnym uwzględnieniem modyfikowalnych czynników ryzyka cukrzycy typu 2.

Słowa kluczowe: wiedza, licealiści, cukrzyca typu 2, czynniki ryzyka

\section{INTRODUCTION}

Diabetes mellitus is referred to as a noncontagious epidemic of the $21^{\text {st }}$ century. According to epidemiological data, the problem of diabetes affects 425 million people, with $90 \%$ being type 2 of the disease $[1,14]$. As reported by the International Diabetes Federation, there were above 2 million adults with type 2 diabetes in Poland in 2019. It was also estimated that 990,000 individuals were undiagnosed [15]. In 2015 diabetes was diagnosed and treated more often among women $(55 \%)$ than men. The studies conducted so far reveal that most of the society are unaware of the risk factors leading to this disease. Excessive body weight, incorrect eating habits and sedentary lifestyle are the main factors that contribute to the risk of diabetes. When detected too late (with already present complications), the treatment presents significantly more difficulties and generates higher costs. Due to the growing prevalence of the disease, prevention and prophylactics of type 2 diabetes should be the key elements of health-oriented education [33]. The awareness of the risk among young people is important as the prevalence can potentially be reduced, which entails a future treatment cost reduction. Moreover, previous studies have mainly assessed the knowledge of adults or people with diabetes. It was therefore decided to evaluate the knowledge about type 2 diabetes and its prevention among secondary school pupils. So far, no specific educational program for young people has been developed. The results of the research could allow for the preparation of educational programs that could potentially reduce the risk of developing this disease in the future [3, 13, 39].

The progress of research on the pathogenesis of type 2 diabetes emphasizes the special importance of environmental factors in the early diagnosis, prevention and treatment of the disease, therefore their detailed analysis is significant $[27,38]$.

Excessive body weight is considered to be one of the major contributors to the development of type 2 diabetes. Recommendations suggest starting a diagnosis for diabetes in people whose BMI exceeds $25 \mathrm{~kg} / \mathrm{m} 2$ - which is overweight according to the WHO scale. Overweight and obesity are found in the majority of patients, with central obesity having a higher diabetogenic effect than gluteal-femoral obesity $[11,38]$. Therefore, the ratio of the waist circumference to the hip circumference WHR - Waist Hip Ratio should be checked.-Waist values in women over $80 \mathrm{~cm}$ and $94 \mathrm{~cm}$ in men place them in the group at increased risk of developing type 2 diabetes. Numerous studies suggest that weight loss is highly effective in preventing and treating type 2 diabetes. People at risk due to this action, they can effectively delay or arrest the onset of the disease. This is due to the increase in tissue insulin sensitivity, which is one of the key mechanisms in the pathogenesis of type 2 diabetes. Weight loss increases glucose and insulin homeostasis, reversing abnormalities in their function and secretion. It is assumed that a $10 \%$ reduction in body weight can effectively prevent the onset of type 2 diabetes in the group of people with pre-diabetes $[7,10]$.

Lifestyle is a key element in the prevention of noncommunicable diseases. Modifying risk factors such as physical inactivity, stress, inappropriate eating habits, smoking or excessive alcohol consumption may reduce the risk of many chronic diseases, including type 2 diabetes $[23,35]$. One of the most serious risk factors for developing type 2 diabetes is low physical activity. Activating the muscles increases the need for glucose by using excess glucose in the body, which prevents hyperglycemia in the body. Increasing physical activity by reducing adipose tissue effectively reduces the risk of developing the disease even up to $35 \%$ [48]. Studies show a positive correlation between a daily 30-minute additional physical activity and a reduction in the risk of developing type 2 diabetes $[8,44]$. Another factor contributing to the occurrence of type 2 diabetes is the presence of long-term stress, which significantly affects the carbohydrate metabolism. Stressful situations contribute to an increase in glycaemia, which results in increased insulin secretion and impairment of insulin sensitivity of tissues. This factor also causes „snacking”, especially sweet, lowvalue products. Irregular meals in combination with the inclusion of sweet snacks between meals in the diet may contribute to an increased risk of developing type 2 diabetes [8]. Inappropriate eating behavior is a leading risk factor for premature death and disability worldwide [9]. There are a number of nutritional factors that can prevent diabetes in healthy people and control glycemia in patients [40].

Lifestyle includes a range of everyday behaviors related to motivation, accepted values and needs, which include, among others, eating behavior. Unfavorable eating behavior contributing to the development of diabetes is primarily too much energy consumed with food. Excessive amount, exceeding the body's energy expenditure, in combination with low physical activity leads to the development of 
overweight and obesity. Irregularity in meals can not only result in nutrient deficiencies, but also contribute to weight gain and the occurrence of dietrelated diseases. Consuming a high-energy meal after a long break leads to a rapid, high increase in glycemia, which results in a rapid insulin release, which activates the process of fatty acid formation, resulting in the accumulation of excessive body fat. However, adherence to the recommended number of meals and regularity of eating them is not sufficient to maintain health. A properly balanced diet should contain wholesome protein, fats with a predominance of mono and polyunsaturated fatty acids and complex carbohydrates along with dietary fiber. There is a lot of scientific evidence confirming the adverse effects of certain groups of nutrients, which, if consumed in excessive amounts, can induce the development of type 2 diabetes. The most important of them are simple sugars, trans fats and saturated fatty acids [46].

Simple sugars are one of the main ingredients that increase the risk of developing type 2 diabetes. These substances are found in fruit juices, sweet fizzy drinks and sweets. In food products, they appear as added sugars, sweeteners or glucose-fructose syrup. The mechanism of action of these substances is based on the direct action of simple carbohydrates, which rapidly increase the level of glycemia, contributing also to weight gain and the development of diabetes. The high proportion of sweet drinks and sweets significantly increases the glycemic load of the diet, which in turn impairs glucose tolerance and the sensitivity of tissues to insulin. Moreover, coloring substances, such as caramel, found in sweet drinks, promote the development of diabetes by increasing the inflammation of the immune system [11, 22]. The effects of fatty acids can have both positive and negative effects on insulin secretion and its reception by tissues. Therefore, it is important to know the types of fats that may have a health-promoting or anti-health effect on the development of type 2 diabetes. The ingredients that should be significantly reduced in the diet are saturated fatty acids and trans fats. Saturated fatty acids are substances found mainly in animal fats such as butter, lard and fatty meats, while trans fats are most often found in hydrogenated margarines and processed foods $[2,12]$. These ingredients not only contribute to the development of diabetes, but also disturb the lipid metabolism and increase the risk of cardiovascular complications [40].

Epidemiological studies increasingly indicate the dangers of smoking and alcohol consumption [18]. However, there are conflicting studies on the effects of alcohol on the human body. Some of them suggest that alcohol in moderate amounts reduces the risk of developing type 2 diabetes, even by 33$56 \%$ [34]. Nevertheless, many authors confirm that alcohol consumed in excess has negative effects on human health. It leads to an increased risk of diabetes, diseases of the cardiovascular system and the liver. Therefore, it should be emphasized that alcohol should be eliminated in the prevention of chronic diseases or limited to a minimum [40]. The mechanism by which smoking tobacco influences the increased risk of developing diabetes is not fully understood. Research suggests that smoking causes increased accumulation of visceral fat, which increases insulin resistance and leads to disease development. It should be noted that smoking cessation significantly reduces the risk of developing many diseases associated with type 2 diabetes, such as cardiovascular or lipid profile disorders [45].

The aim of the study was to evaluate the knowledge about risk factors for type 2 diabetes among secondary school students and to determine whether there are differences between the level of knowledge between girls and boys and between first-, second- and thirdgrade students.

\section{MATERIAL AND METHODS}

The authors obtained the consent of the management to conduct the research. Moreover, study participants gave their written consent to participate in the study. The study involved 650 students (at the age of 16.9 \pm 0.8 years) of comprehensive secondary schools in the Silesian Province, Poland. A self-constructed questionnaire consisted of the demographic part and the proper questions, enquiring about risk factors and potential complications of type 2 diabetes mellitus. The proper part was preceded by a pilot study among 30 students. Finally, 643 respondents, who answered the questions as instructed, were included in the analysis.

The characteristics of the studied group are presented in Table 1.

Table 1.Characteristics of the studied group

\begin{tabular}{|c|c|c|c|}
\hline \multicolumn{2}{|c|}{ Feature } & n & \% \\
\hline \multirow{2}{*}{ Gender } & Women & 413 & 64.2 \\
\cline { 2 - 4 } & Men & 230 & 35.8 \\
\hline \multirow{3}{*}{ Class } & I & 227 & 35.3 \\
\cline { 2 - 4 } & II & 227 & 35.3 \\
\cline { 2 - 4 } & III & 189 & 29.4 \\
\hline \multicolumn{2}{|c|}{ Total } & 643 & 100.0 \\
\hline
\end{tabular}

When evaluating the students' knowledge, a correct answer was awarded 1 point, while wrong answers were not given any points. The maximum score was 36 . The knowledge of students was determined using three levels: low $<0-40 \%)$, average $(40-70 \%)$ and $(70-100 \%)$ high. The responses were analysed jointly 
and after sex- and grade-based division. The results were collected in Microsoft Excel 2010, and statistical calculations were performed in Statistica 13.3 (TIBCO Inc.). First, it was checked if quantitative variables meet the normal distribution assumption; this was done with the Shapiro-Wilk W test and normality diagrams. Differences in the percentages of correct answers provided by girls and boys were evaluated with the Mann-Whitney $U$ test. As for determining differences between the percentages of correct answers provided by first-, second- and third-graders, the Kruskal-Wallis ANOVA was applied; a two-sided post hoc test was used with Bonferroni correction. For all analyses, the value of $\mathrm{p}<0.05$ was considered statistically significant.

\section{RESULTS}

The joint analysis of the students' responses to the proper part of the questionnaire is presented in Tables 2-4.

The correct definition of type 2 diabetes was indicated by $63.9 \%$ of the respondents, more girls than boys $(66.8 \%$ vs $58.7 \%)$, with most correct answers given by third-grade students $(66.1 \%)$. The responses concerning risk factors for type 2 diabetes varied; $62.5 \%$ of the respondents stated that the risk increased with age. This answer was provided by more boys (69.1\%) than girls $(58.8 \%)$, and mostly by secondgrade students (66.5\%). The correct answer about age after which the risk of the disease increases was indicated by $40.9 \%$ of the students, including $40.4 \%$ of girls and $41.7 \%$ of boys. Most such answers were given by second-grade students (43.2\%). The relationship between excessive body weight and increased risk of type 2 diabetes was indicated by $92.9 \%$ of the students, including $91.8 \%$ of girls and $94.8 \%$ of boys. Most correct answers were noted in third-graders. The abdominal type of obesity (android-type) was indicated as a risk factor for diabetes by $18.5 \%$ of the respondents, more girls $(19.6 \%)$ than boys $(16.5 \%)$, with most such answers given by first-grade students $(20.7 \%)$. Cardiovascular diseases were selected by $52.3 \%$ of the students, including $52.1 \%$ of girls and $52.6 \%$ of boys; most correct answers were noted in the group of third-graders $(61.9 \%)$. Hypertension as a risk factor for diabetes was indicated by $56 \%$ of the respondents, more girls than boys $(57.6 \%$ vs $53.5 \%$ ), with most such answers given by secondgrade students $(60.4 \%)$. Dyslipidaemia as a disease predisposing to type 2 diabetes was indicated by $67.7 \%$ of the students, including $69.5 \%$ of girls and $64.8 \%$ of boys; most such answers were noted in the group of first-grade students (69.6\%) (Table 2).

Polycystic ovary syndrome (PCOS) as a disease that raises the risk of type 2 diabetes was indicated by only
$4.8 \%$ of the respondents, more girls than boys $(5.3 \%$ vs $3.9 \%$ ), with most such answers given by third-graders $(9.5 \%)$. Most of the students indicated a relationship between long-term use of steroid drugs and increased risk for type 2 diabetes. This response was provided by $74 \%$ of the students, including $77 \%$ of girls and $68.7 \%$ of boys, with most such answers in the group of third-graders $(82 \%)$. Smoking was selected by $28.8 \%$ of the students, including $27.1 \%$ of girls and $31.7 \%$ of boys, and most second-graders (31.3\%). Genetic predisposition was selected by $27.5 \%$ of the students, including $27.6 \%$ of girls and $27.4 \%$ of boys, and most second-graders (30.8\%). Gestational diabetes as a risk factor for type 2 diabetes was indicated by $60 \%$ of the girls and boys, with most such responses in the group of third-graders, while neonatal birth weight (over $4 \mathrm{~kg}$ ) was selected by $26.3 \%$ of the respondents, including $26.4 \%$ girls and $26.1 \%$ of boys, and most first-grade students (29.1\%). The effect of eating habits on the occurrence of type 2 diabetes was indicated by $92.4 \%$ of the respondents, including $93.2 \%$ of girls and $90.9 \%$ of boys, and most third-graders - $93.7 \%$ (Table 3).

The responses concerning selected nutritious factors conductive to type 2 diabetes varied. Too calorific foods were selected by $27.6 \%$ of the students, including $27.3 \%$ of girls and $28.2 \%$ of boys. Most correct answers were noted in first-graders. Too high intake of mono- and disaccharides was selected by $92.6 \%$ of the students, including $92.7 \%$ of girls and $92.3 \%$ of boys; most such answers were noted in the group of third-graders $(95.5 \%)$. Dietary fibre restriction as a factor leading to diabetes was indicated by $27.4 \%$ of the respondents, more girls than boys (28.6\% vs $25.4 \%$ ). Most correct answers were noted in first-graders $(29.5 \%)$. Too high fat intake was selected by $43.9 \%$ of the students, including $45.7 \%$ of girls and $40.7 \%$ of boys, and most second-graders (46.9\%). Too low physical activity levels were indicated by $85.7 \%$ of the students, more girls than boys: $86 \%$ and $85.2 \%$, respectively. Most correct answers were noted in first-graders $(87.2 \%)$. Chronic stress as a risk factor for type 2 diabetes was indicated by $51.2 \%$ of the respondents, more boys than girls ( $53 \%$ vs $50 \%$ ), with most correct answers given by third-grade students (57.1\%) (Table 4).

Prediabetes as a factor preceding diabetes was selected by $77.3 \%$ of the students, including $77.2 \%$ of girls and $77.4 \%$ of boys, and most second-graders $(81.9 \%)$. Nerve injury as a consequence of untreated or inappropriately treated diabetes was indicated by $13.2 \%$ of the students, more boys than girls $(17 \%$ vs $11.1 \%)$. Most correct answers were given by secondgrade students $(15 \%)$. Diabetic foot syndrome was selected by $73.4 \%$ of the students, including $73.4 \%$ of girls and $73.5 \%$ of boys, and most second-graders (74\%). Kidney diseases as a complication of type 2 
Table 2. The joint analysis of the students' responses to the selected questions evaluating the students' knowledge (part 1)

\begin{tabular}{|c|c|c|c|c|c|c|c|c|c|c|c|c|}
\hline \multirow{3}{*}{ Possible answers } & \multicolumn{4}{|c|}{ Gender } & \multicolumn{6}{|c|}{ Class } & \multirow{2}{*}{\multicolumn{2}{|c|}{ Total }} \\
\hline & \multicolumn{2}{|c|}{ Women } & \multicolumn{2}{|c|}{ Men } & \multicolumn{2}{|c|}{ I } & \multicolumn{2}{|c|}{ II } & \multicolumn{2}{|c|}{ III } & & \\
\hline & $\mathrm{n}$ & $\%$ & $\mathrm{n}$ & $\%$ & $\mathrm{n}$ & $\%$ & $\mathrm{n}$ & $\%$ & $\mathrm{n}$ & $\%$ & $\mathrm{n}$ & $\%$ \\
\hline \multicolumn{13}{|c|}{ 1. Type 2 diabetes is a disease caused by: } \\
\hline It decreases with age & 54 & 13.1 & 37 & 16.1 & 31 & 13.7 & 32 & 14.1 & 28 & 14.8 & 91 & 14.2 \\
\hline Taking too much sugar & 83 & 20.1 & 58 & 25.2 & 55 & 24.2 & 50 & 22.0 & 36 & 19.1 & 141 & 21.9 \\
\hline $\begin{array}{l}\text { Progressive impairment } \\
\text { of insulin secretion } \\
\text { in conditions of insulin } \\
\text { resistance }\end{array}$ & 276 & 66.8 & 135 & 58.7 & 141 & 62.1 & 145 & 63.9 & 125 & 66.1 & 411 & 63.9 \\
\hline
\end{tabular}

\section{The influence of age on the risk of developing type 2 diabetes:}

\begin{tabular}{|l|c|c|c|c|c|c|c|c|c|c|c|c|}
\hline It decreases with age & 3 & 0.7 & 5 & 2.2 & 5 & 2.2 & 2 & 0.9 & 1 & 0.5 & 8 & 1.3 \\
\hline It grows with age & 243 & 58.8 & 159 & 69.1 & 130 & 57.3 & 151 & 66.5 & 121 & 64.0 & 402 & 62.5 \\
\hline $\begin{array}{l}\text { It does not affect the } \\
\text { occurrence of the disease }\end{array}$ & 167 & 40.5 & 66 & 28.7 & 92 & 40.5 & 74 & 32.6 & 67 & 35.5 & 233 & 36.3 \\
\hline
\end{tabular}

3. There is an increased risk of developing type 2 diabetes in people :

\begin{tabular}{|l|c|c|c|c|c|c|c|c|c|c|c|c|}
\hline Over 45 years old & 167 & 40.4 & 96 & 41.7 & 87 & 38.3 & 98 & 43.2 & 78 & 41.3 & 263 & 40.9 \\
\hline Over 60 years old & 85 & 20.6 & 63 & 27.4 & 53 & 23.3 & 54 & 23.8 & 41 & 21.7 & 148 & 23.0 \\
\hline Regardless of age & 161 & 39.0 & 71 & 30.9 & 87 & 38.3 & 75 & 33.0 & 70 & 37.0 & 232 & 36.1 \\
\hline
\end{tabular}

4. The effect of excessive body weight on the risk of developing type 2 diabetes:

\begin{tabular}{|l|c|c|c|c|c|c|c|c|c|c|c|c|}
\hline$\uparrow$ risk of getting illness & 379 & 91.8 & 218 & 94.8 & 207 & 91.2 & 209 & 92.1 & 181 & 95.8 & 597 & 92.9 \\
\hline$\downarrow$ risk of getting illness & 5 & 1.2 & 3 & 1.3 & 1 & 0.4 & 4 & 1.8 & 3 & 1.6 & 8 & 1.2 \\
\hline $\begin{array}{l}\text { It does not affect the } \\
\text { occurrence of the disease }\end{array}$ & 7 & 7.0 & 9 & 3.9 & 19 & 8.4 & 14 & 6.2 & 5 & 2.6 & 38 & 5.9 \\
\hline
\end{tabular}

5. The influence of obesity on the risk of developing type 2 diabetes:

\begin{tabular}{|l|c|c|c|c|c|c|c|c|c|c|c|c|}
\hline $\begin{array}{l}\text { Type 2 diabetes leads to } \\
\text { obesity }\end{array}$ & 91 & 22.0 & 53 & 23.0 & 49 & 21.6 & 48 & 21.1 & 47 & 24.9 & 144 & 22.4 \\
\hline $\begin{array}{l}\text { Gynoid obesity } \uparrow \uparrow \text { risk of } \\
\text { getting illness }\end{array}$ & 19 & 4.6 & 20 & 8.7 & 13 & 5.7 & 20 & 8.8 & 6 & 3.2 & 39 & 6.1 \\
\hline $\begin{array}{l}\text { Abdominal obesity } \uparrow \text { risk } \\
\text { of getting illness }\end{array}$ & 81 & 19.6 & 38 & 16.5 & 47 & 20.7 & 37 & 16.3 & 35 & 18.5 & 119 & 18.5 \\
\hline $\begin{array}{l}\text { It does not affect the } \\
\text { occurrence of the disease }\end{array}$ & 222 & 53.8 & 119 & 51.8 & 118 & 52.0 & 122 & 53.7 & 101 & 53.4 & 431 & 53.0 \\
\hline
\end{tabular}

6.1. Diseases predisposing to type 2 diabetes - cardiovascular diseases:

\begin{tabular}{|l|l|l|l|l|l|l|l|l|l|l|l|l|}
\hline Yes & 215 & 52.1 & 121 & 52.6 & 109 & 48.0 & 110 & 48.5 & 117 & 61.9 & 336 & 52.3 \\
\hline No & 198 & 47.9 & 109 & 47.4 & 118 & 52.0 & 117 & 51.5 & 72 & 38.1 & 307 & 47.7 \\
\hline
\end{tabular}

6.2. Diseases predisposing to type 2 diabetes - arterial hypertension:

\begin{tabular}{|l|c|c|c|c|c|c|c|c|c|c|c|c|}
\hline Yes & 238 & 57.6 & 123 & 53.5 & 130 & 57.3 & 137 & 60.4 & 94 & 49.7 & 361 & 56.0 \\
\hline No & 175 & 42.4 & 107 & 46.5 & 97 & 42.7 & 90 & 39.6 & 95 & 50.3 & 282 & 44.0 \\
\hline \multicolumn{1}{|c|}{ 6.3. Diseases predisposing to type 2 diabetes - dyslipidaemia: } \\
\hline Yes & 287 & 69.5 & 149 & 64.8 & 158 & 69.6 & 157 & 69.2 & 121 & 64.0 & 436 & 67.8 \\
\hline No & 126 & 30.5 & 81 & 35.2 & 69 & 30.4 & 70 & 30.8 & 68 & 36.0 & 207 & 32.2 \\
\hline
\end{tabular}


Table 3. The joint analysis of the students' responses to the selected questions evaluating the students' knowledge (part 2)

\begin{tabular}{|c|c|c|c|c|c|c|c|c|c|c|c|c|}
\hline \multirow{3}{*}{ Possible answers } & \multicolumn{4}{|c|}{ Gender } & \multicolumn{6}{|c|}{ Class } & \multirow{2}{*}{\multicolumn{2}{|c|}{ Total }} \\
\hline & \multicolumn{2}{|c|}{ Women } & \multicolumn{2}{|c|}{ Men } & \multicolumn{2}{|c|}{ I } & \multicolumn{2}{|c|}{ II } & \multicolumn{2}{|c|}{ III } & & \\
\hline & $\mathrm{n}$ & $\%$ & $\mathrm{n}$ & $\%$ & $\mathrm{n}$ & $\%$ & $\mathrm{n}$ & $\%$ & $\mathrm{n}$ & $\%$ & $\mathrm{n}$ & $\%$ \\
\hline
\end{tabular}

6.4. Diseases predisposing to type 2 diabetes - polycystic ovary syndrome:

\begin{tabular}{|c|c|c|c|c|c|c|c|c|c|c|c|c|}
\hline Yes & 22 & 5.3 & 9 & 3.9 & 8 & 3.5 & 5 & 2.2 & 18 & 9.5 & 31 & 4.8 \\
\hline No & 391 & 94.7 & 221 & 96.1 & 219 & 96.5 & 222 & 97.8 & 171 & 90.5 & 612 & 95.2 \\
\hline
\end{tabular}

6.5. Diseases predisposing to type 2 diabetes - respiratory diseases:

\begin{tabular}{|c|c|c|c|c|c|c|c|c|c|c|c|c|}
\hline Yes & 15 & 3.6 & 11 & 4.8 & 9 & 4.0 & 11 & 4.8 & 6 & 3.2 & 26 & 4.0 \\
\hline No & 398 & 96.4 & 219 & 95.2 & 218 & 96.0 & 216 & 95.2 & 183 & 96.8 & 617 & 96.0 \\
\hline
\end{tabular}

7.1. Selected factors affecting the prevalence of type 2 diabetes - long-term use of steroid drugs:

\begin{tabular}{|c|c|c|c|c|c|c|c|c|c|c|c|c|}
\hline Yes & 318 & 77.0 & 158 & 68.7 & 166 & 73.1 & 155 & 68.3 & 155 & 82.0 & 476 & 74.0 \\
\hline No & 95 & 23.0 & 72 & 31.3 & 61 & 26.9 & 72 & 31.7 & 34 & 18.0 & 167 & 26.0 \\
\hline
\end{tabular}

7.2. Selected factors affecting the prevalence of type 2 diabetes - long-term smoking:

\begin{tabular}{|c|c|c|c|c|c|c|c|c|c|c|c|c|}
\hline Yes & 112 & 27.1 & 73 & 31.7 & 58 & 25.6 & 71 & 31.3 & 56 & 29.6 & 185 & 28.8 \\
\hline No & 301 & 72.9 & 157 & 68.3 & 169 & 74.4 & 156 & 68.7 & 133 & 70.4 & 458 & 71.2 \\
\hline
\end{tabular}

7.2. Selected factors affecting the prevalence of type 2 diabetes - genetic determinants:

\begin{tabular}{|c|c|c|c|c|c|c|c|c|c|c|c|c|}
\hline Yes & 114 & 27.6 & 63 & 27.4 & 54 & 23.8 & 70 & 30.8 & 53 & 28.0 & 177 & 27.5 \\
\hline No & 299 & 72.4 & 167 & 72.6 & 173 & 72.6 & 157 & 69.2 & 136 & 72.0 & 466 & 72.5 \\
\hline
\end{tabular}

8.1. Pregnancy related factors affecting the prevalence of type 2 diabetes - prevalence of gestational diabetes mellitus:

\begin{tabular}{|c|c|c|c|c|c|c|c|c|c|c|c|c|}
\hline Yes & 248 & 60.0 & 138 & 60.0 & 126 & 55.5 & 134 & 59.0 & 126 & 66.7 & 386 & 60.0 \\
\hline No & 165 & 40.0 & 92 & 40.0 & 101 & 44.5 & 93 & 41.0 & 63 & 33.3 & 257 & 40.0 \\
\hline
\end{tabular}

8.2. Pregnancy related factors affecting the prevalence of type 2 diabetes - birth weight of the child:

\begin{tabular}{|c|c|c|c|c|c|c|c|c|c|c|c|c|}
\hline Less 4 kg & 25 & 6.1 & 17 & 7.4 & 17 & 7.5 & 14 & 6.2 & 11 & 5.8 & 42 & 6.5 \\
\hline Above 4 kg & 109 & 26.4 & 60 & 26.1 & 66 & 29.1 & 49 & 21.6 & 54 & 28.6 & 169 & 26.3 \\
\hline $\begin{array}{c}\text { It does not affect the } \\
\text { occurrence of the disease }\end{array}$ & 279 & 67.6 & 153 & 66.5 & 144 & 63.0 & 164 & 72.2 & 65 & 65.6 & 432 & 67.2 \\
\hline
\end{tabular}

9. The influence of eating habits on the prevalence of type 2 diabetes:

\begin{tabular}{|c|c|c|c|c|c|c|c|c|c|c|c|c|}
\hline Yes & 385 & 93.2 & 209 & 90.9 & 210 & 92.5 & 207 & 91.2 & 177 & 93.7 & 594 & 92.4 \\
\hline No & 28 & 6.8 & 21 & 9.1 & 17 & 7.5 & 20 & 8.8 & 12 & 6.3 & 49 & 7.6 \\
\hline
\end{tabular}


Table 4. The joint analysis of the students' responses to the selected questions evaluating the students' knowledge (part 3)

\begin{tabular}{|c|c|c|c|c|c|c|c|c|c|c|c|c|}
\hline \multirow{3}{*}{ Possible answers } & \multicolumn{4}{|c|}{ Gender } & \multicolumn{6}{|c|}{ Class } & \multirow{2}{*}{\multicolumn{2}{|c|}{ Total }} \\
\hline & \multicolumn{2}{|c|}{ Women } & \multicolumn{2}{|c|}{ Men } & \multicolumn{2}{|c|}{ I } & \multicolumn{2}{|c|}{ II } & \multicolumn{2}{|c|}{ III } & & \\
\hline & $\mathrm{n}$ & $\%$ & $\mathrm{n}$ & $\%$ & $\mathrm{n}$ & $\%$ & $\mathrm{n}$ & $\%$ & $\mathrm{n}$ & $\%$ & $\mathrm{n}$ & $\%$ \\
\hline
\end{tabular}

10.1. Selected nutritional factors that can lead to type 2 diabetes - too energetic meals::

\begin{tabular}{|c|c|c|c|c|c|c|c|c|c|c|c|c|}
\hline Yes & 105 & 27.3 & 59 & 28.2 & 59 & 28.1 & 57 & 27.5 & 48 & 27.1 & 164 & 27.6 \\
\hline No & 280 & 72.7 & 150 & 71.8 & 151 & 71.9 & 150 & 72.5 & 129 & 72.9 & 430 & 72.4 \\
\hline
\end{tabular}

10.2. Selected nutritional factors that can lead to type 2 diabetes - excessive amounts of simple sugars and disaccharides:

\begin{tabular}{|c|c|c|c|c|c|c|c|c|c|c|c|c|}
\hline Yes & 357 & 92.7 & 193 & 92.3 & 193 & 91.9 & 188 & 90.8 & 169 & 95.5 & 550 & 92.6 \\
\hline No & 28 & 7.3 & 16 & 7.7 & 17 & 8.1 & 19 & 9.2 & 8 & 4.5 & 44 & 7.4 \\
\hline
\end{tabular}

10.3. Selected nutritional factors that can lead to type 2 diabetes - dietary fiber restriction:

\begin{tabular}{|l|c|c|c|c|c|c|c|c|c|c|c|c|}
\hline Yes & 110 & 28.6 & 53 & 25.4 & 62 & 29.5 & 51 & 24.6 & 50 & 28.2 & 163 & 27.4 \\
\hline No & 275 & 71.4 & 156 & 74.6 & 148 & 70.5 & 156 & 75.4 & 127 & 71.8 & 431 & 72.6 \\
\hline 10.4. Selected nutritional factors that can lead to type 2 diabetes - excessive water supply: \\
\hline Yes & 10 & 2.6 & 5 & 2.4 & 3 & 1.4 & 9 & 4.3 & 3 & 1.7 & 15 & 27.4 \\
\hline No & 375 & 97.4 & 204 & 97.6 & 207 & 98.6 & 198 & 95.7 & 174 & 98.3 & 579 & 97.5 \\
\hline
\end{tabular}

10.5. Selected nutritional factors that can lead to type 2 diabetes - excessive consumption of animal fats:

\begin{tabular}{|c|c|c|c|c|c|c|c|c|c|c|c|c|}
\hline Yes & 176 & 45.7 & 85 & 40.7 & 90 & 42.9 & 97 & 46.9 & 74 & 41.8 & 261 & 43.9 \\
\hline No & 209 & 54.3 & 124 & 59.3 & 120 & 57.1 & 110 & 53.1 & 103 & 58.2 & 333 & 56.1 \\
\hline
\end{tabular}

11.1. Selected factors that can lead to type 2 diabetes - too little physical activity:

\begin{tabular}{|c|c|c|c|c|c|c|c|c|c|c|c|c|}
\hline Yes & 355 & 86.0 & 196 & 85.2 & 198 & 87.2 & 190 & 83.7 & 163 & 86.2 & 551 & 85.7 \\
\hline No & 58 & 14.0 & 34 & 14.8 & 29 & 12.8 & 37 & 16.3 & 26 & 13.8 & 92 & 14.3 \\
\hline
\end{tabular}

11.2. Selected factors that can lead to type 2 diabetes - extreme sports:

\begin{tabular}{|c|c|c|c|c|c|c|c|c|c|c|c|c|}
\hline Yes & 9 & 2.0 & 5 & 2.0 & 4 & 1.8 & 6 & 2.6 & 4 & 2.1 & 14 & 2.2 \\
\hline No & 404 & 98.0 & 225 & 98.0 & 223 & 98.2 & 221 & 97.4 & 185 & 97.9 & 629 & 97.8 \\
\hline \multicolumn{7}{|c|}{ 11.3. Selected factors that can lead to type 2 diabetes - chronic stress: } \\
\hline Yes & 206 & 50.0 & 123 & 53.0 & 120 & 52.9 & 101 & 44.5 & 108 & 57.1 & 329 & 51.2 \\
\hline No & 207 & 50.0 & 107 & 47.0 & 107 & 47.1 & 126 & 55.5 & 81 & 42.9 & 314 & 48.8 \\
\hline
\end{tabular}

11.4. Selected factors that can lead to type 2 diabetes - maintaining body weight below the recommended standard:

\begin{tabular}{|c|c|c|c|c|c|c|c|c|c|c|c|c|}
\hline Yes & 70 & 16.9 & 42 & 18.3 & 50 & 22.0 & 31 & 13.7 & 31 & 16.4 & 112 & 17.4 \\
\hline No & 343 & 83.1 & 188 & 81.7 & 177 & 78.0 & 196 & 86.3 & 158 & 83.6 & 531 & 82.6 \\
\hline
\end{tabular}

11.5. Selected factors that can lead to type 2 diabetes - the occurrence of the disease in your spouse:

\begin{tabular}{|c|c|c|c|c|c|c|c|c|c|c|c|c|}
\hline Yes & 12 & 2.9 & 12 & 5.2 & 8 & 3.5 & 7 & 3.1 & 9 & 4.8 & 24 & 3.7 \\
\hline No & 401 & 97.1 & 218 & 94.8 & 219 & 96.5 & 220 & 96.9 & 180 & 95.8 & 619 & 96.3 \\
\hline
\end{tabular}


diabetes was selected by $37.5 \%$ of the respondents, more boys than girls $(45.7 \%$ vs $32.9 \%$ ), with most correct answers given by second-grade students (46\%). Depression was selected by a total of $17.4 \%$ of the students, including $18.2 \%$ of girls and $21.3 \%$ of boys, and most third-graders (22.8\%). Eye diseases were selected by $17.4 \%$ of the students, more boys than girls (19.1\% and 16.5\%). Most such answers were given by second-grade students (20.3\%). Recurrent infections as a complication of diabetes were indicated by $21.3 \%$ of the students, more girls than boys: $23.5 \%$ and $17.4 \%$, respectively, with most such answers in the group of first-graders (24.7\%) (Table 5).

Table 5. The joint analysis of the students' responses to the selected questions evaluating the students' knowledge (part 4)

\begin{tabular}{|c|c|c|c|c|c|c|c|c|c|c|c|c|}
\hline \multirow{3}{*}{ Possible answers } & \multicolumn{4}{|c|}{ Gender } & \multicolumn{6}{|c|}{ Class } & \multirow{2}{*}{\multicolumn{2}{|c|}{ Total }} \\
\hline & \multicolumn{2}{|c|}{ Women } & \multicolumn{2}{|c|}{ Men } & \multicolumn{2}{|c|}{ I } & \multicolumn{2}{|c|}{ II } & \multicolumn{2}{|c|}{ III } & & \\
\hline & $\mathrm{n}$ & $\%$ & $\mathrm{n}$ & $\%$ & $\mathrm{n}$ & $\%$ & $\mathrm{n}$ & $\%$ & $\mathrm{n}$ & $\%$ & $\mathrm{n}$ & $\%$ \\
\hline \multicolumn{13}{|c|}{ 11.6. Selected factors that may lead to type 2 diabetes - pre-diabetes: } \\
\hline Yes & 319 & 77.2 & 178 & 77.4 & 175 & 77.1 & 186 & 81.9 & 136 & 72.0 & 497 & 77.3 \\
\hline No & 94 & 22.8 & 52 & 22.6 & 52 & 22.9 & 41 & 18.1 & 53 & 28.0 & 146 & 22.7 \\
\hline \multicolumn{13}{|c|}{ 12.1. Complications of type 2 diabetes - nerve damage: } \\
\hline Yes & 46 & 11.1 & 39 & 17.0 & 23 & 10.1 & 34 & 15.0 & 28 & 14.8 & 85 & 13.2 \\
\hline No & 367 & 88.9 & 191 & 83.0 & 204 & 89.9 & 193 & 85.0 & 161 & 85.2 & 558 & 86.8 \\
\hline \multicolumn{13}{|c|}{ 12.2. Complications of type 2 diabetes - chronic obstructive pulmonary disease: } \\
\hline Yes & 31 & 7.5 & 18 & 7.8 & 17 & 7.5 & 22 & 9.7 & 10 & 5.3 & 49 & 7.6 \\
\hline No & 382 & 92.5 & 212 & 92.2 & 210 & 92.5 & 205 & 90.3 & 179 & 94.7 & 594 & 92.4 \\
\hline \multicolumn{13}{|c|}{ 12.3. Complications of type 2 diabetes - asthma: } \\
\hline Yes & 44 & 10.7 & 36 & 15.7 & 38 & 16.7 & 28 & 12.3 & 14 & 7.4 & 80 & 12.4 \\
\hline No & 369 & 89.3 & 194 & 84.3 & 189 & 88.3 & 199 & 87.7 & 175 & 92.6 & 563 & 87.6 \\
\hline \multicolumn{13}{|c|}{ 12.4. Complications of type 2 diabetes - diabetic foot syndrome: } \\
\hline Yes & 303 & 73.4 & 169 & 73.5 & 167 & 73.6 & 168 & 74.0 & 137 & 72.5 & 472 & 73.4 \\
\hline No & 110 & 26.6 & 61 & 26.5 & 60 & 26.4 & 59 & 26.0 & 52 & 27.5 & 171 & 26.6 \\
\hline \multicolumn{13}{|c|}{ 12.5. Complications of type 2 diabetes - kidney disease: } \\
\hline Yes & 136 & 32.9 & 105 & 45.7 & 81 & 35.7 & 73 & 32.2 & 87 & 46.0 & 241 & 37.5 \\
\hline No & 277 & 67.1 & 125 & 54.3 & 146 & 64.3 & 154 & 67.8 & 102 & 54.0 & 402 & 62.5 \\
\hline \multicolumn{13}{|c|}{ 12.6. Complications of type 2 diabetes - depression: } \\
\hline Yes & 75 & 18.2 & 49 & 21.3 & 38 & 16.7 & 43 & 18.9 & 43 & 22.8 & 124 & 19.3 \\
\hline No & 338 & 81.8 & 18.1 & 78.7 & 189 & 83.3 & 184 & 81.1 & 146 & 77.2 & 519 & 80.7 \\
\hline \multicolumn{13}{|c|}{ 12.7. Complications of type 2 diabetes - eye diseases: } \\
\hline Yes & 68 & 16.5 & 44 & 19.1 & 33 & 14.5 & 46 & 20.3 & 33 & 17.5 & 112 & 17.4 \\
\hline No & 345 & 83.5 & 186 & 80.9 & 194 & 85.5 & 181 & 79.7 & 156 & 82.5 & 531 & 82.6 \\
\hline \multicolumn{13}{|c|}{ 12.8. Complications of type 2 diabetes - diseases of the cardiovascular system: } \\
\hline Yes & 224 & 59.1 & 146 & 63.5 & 134 & 59.0 & 141 & 62.1 & 115 & 60.8 & 390 & 60.7 \\
\hline No & 169 & 40.9 & 84 & 36.5 & 93 & 41.0 & 86 & 37.9 & 74 & 39.2 & 253 & 39.3 \\
\hline \multicolumn{13}{|c|}{ 12.9. Complications of type 2 diabetes - occurrence of recurrent infections: } \\
\hline Yes & 97 & 23.5 & 40 & 17.4 & 56 & 24.7 & 48 & 21.1 & 33 & 17.5 & 137 & 21.3 \\
\hline No & 316 & 76.5 & 190 & 82.6 & 171 & 75.3 & 179 & 78.9 & 156 & 82.5 & 506 & 78.7 \\
\hline
\end{tabular}


The Shapiro-Wilk $\mathrm{W}$ test and normality diagrams showed that the percentage of correct answers did not meet the normality distribution assumption. There were statistically significant differences between the percentage of correct answers provided by first-, secondand third-grade students. There were no statistically significant differences between the percentage of correct answers provided by girls and boys (Table 6).

A two-sided post hoc test with Bonferroni correction revealed statistically significant differences between the percentage of correct responses provided by first- and third-grade students $(\mathrm{p}<0.02)$.
The knowledge of the respondents was classified to three levels. Average knowledge was noted for $89.6 \%$ of the students, including $89.3 \%$ of girls and $90 \%$ of boys, as well as $89.9 \%$ of first-, second- and thirdgraders each (Figure 1).

Forty-seven per cent of the respondents assessed their knowledge as insufficient. This included $46.7 \%$ of females and $47.4 \%$ of males as well as $41.4 \%$ of firstgraders, $52.9 \%$ of second-graders and $46.6 \%$ of thirdgraders (Figure 2).

Table 6. The percentage of correct answers provided by the respondents to questions checking their knowledge

\begin{tabular}{|c|c|c|c|c|}
\hline \multicolumn{2}{|c|}{ Feature } & Median & $\begin{array}{c}\text { Lower }- \text { upper } \\
\text { quartile }\end{array}$ & Name and test result \\
\hline \multirow{3}{*}{ Gender } & Women & 54.17 & $47.22-61.11$ & \multirow{2}{*}{$\begin{array}{c}\text { Mann-Whitney U test; } \\
\mathrm{p}=0.890\end{array}$} \\
\cline { 2 - 4 } & Men & 52.78 & $47.22-61.11$ & \multirow{2}{*}{$\begin{array}{c}\text { Kruskal-Wallis ANOVA; } \\
\mathrm{p}=0.028\end{array}$} \\
\cline { 2 - 4 } Class & I & 52.78 & $47.22-61.11$ & \\
\cline { 2 - 5 } & II & 52.78 & $47.22-61.11$ & $50.00-61.11$ \\
\hline \multicolumn{2}{|c|}{ III } & 55.56 & $47.22-61.11$ & \\
\hline
\end{tabular}

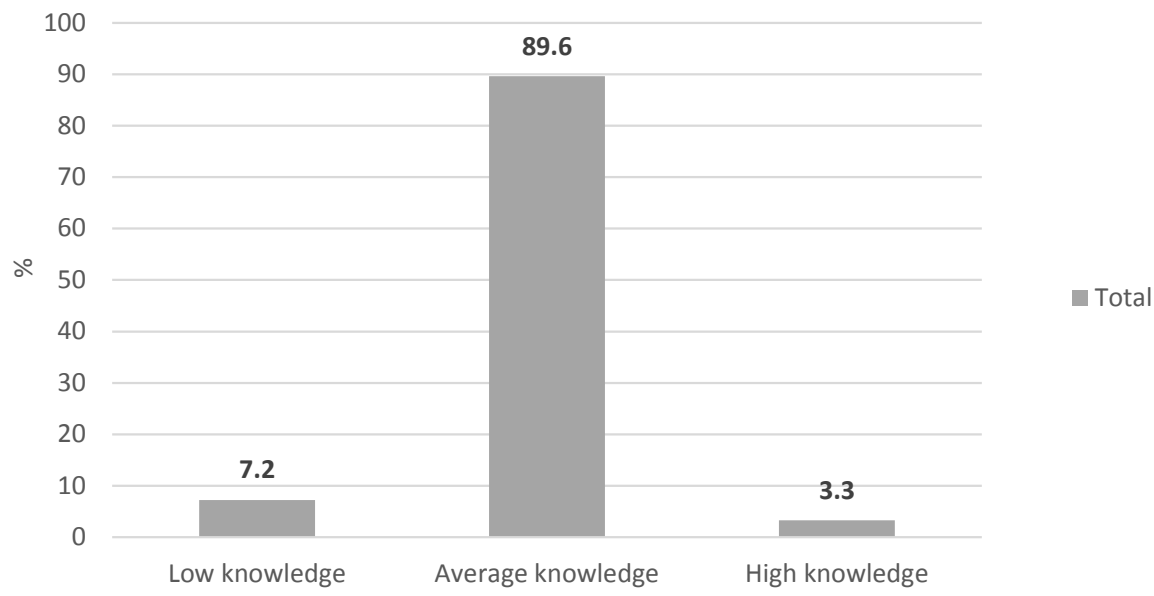

Figure 1. Knowledge on type 2 diabetes of the respondents

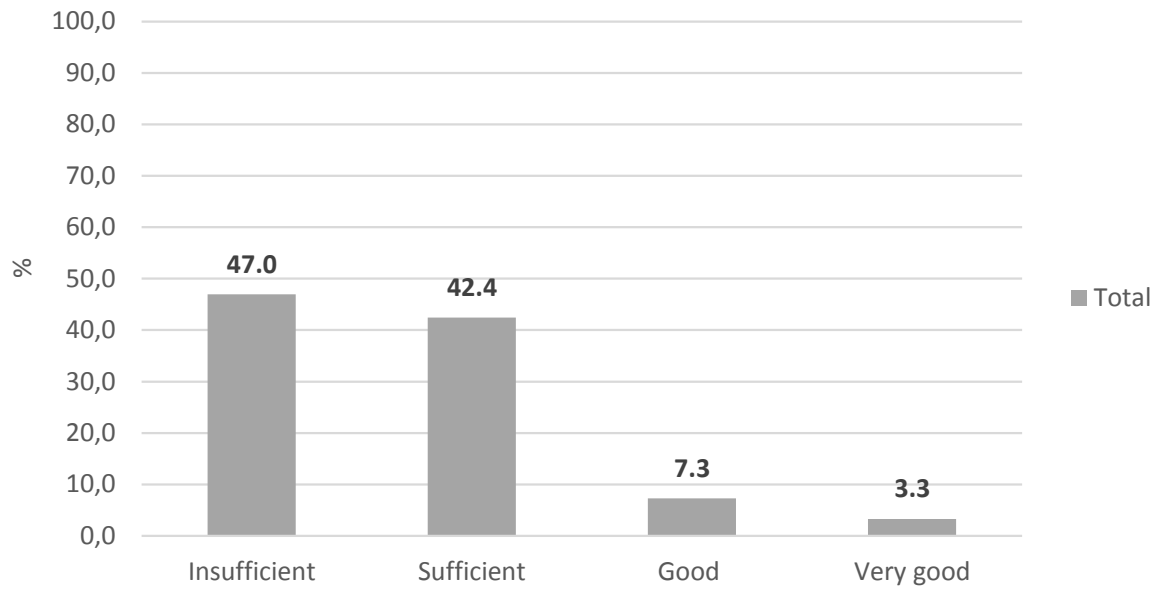

Figure 2. Self-assessment of the respondents' knowledge on type 2 diabetes 


\section{DISCUSSION}

Over the past years, prevention of type 2 diabetes mellitus has become one of the key challenges of contemporary medicine. The available research mostly focuses on the assessments of knowledge among diabetes patients rather than of risk factors for the disease, particularly in young people [40]. In this questionnaire, the correct definition of diabetes was recognised by $63.9 \%$ of the students. Similar results were obtained by Rybarczyk-Szwajkowska, who evaluated the knowledge of threats associated with lifestyle diseases among 475 students of higher schools in Polish city Łódź, University of Vienna and National Medical University in Kiev. The correct definition of type 2 diabetes was indicated by $66.67 \%$ of the respondents from Kiev, $51.35 \%$ of the respondents from Lodz and $40.6 \%$ of the students from Vienna [32]. In this study, $62.5 \%$ of the students indicated a relationship between age and increased risk of type 2 diabetes. This relationship is confirmed by the NHANES report which presented the prevalence of diabetes in given age groups: $3.7 \%$ for the group of 20 - 44 year-olds, $13.7 \%$ for the group of 45 - 64 yearolds and $26.9 \%$ for the group of $\geq 65$ year-olds. These data are reflected in recommendations of the Polish Diabetes Association where the need for screening for diabetes mellitus every 3 years is underlined, particularly in individuals over 45 years of age [29]. In the present study, $40.9 \%$ of the respondents selected the age of 45 years as the age after which screening should begin. Janeczek et al. [16] obtained different results in their study regarding the knowledge about type 2 diabetes among nursing students. Only 3\% of the respondents indicated the need for screening every 3 years after the age of 45 years, while $94 \%$ of the students selected annual screening.

Overweight and obesity more and more frequently contribute to the increased prevalence of type 2 diabetes. This is caused by long-term exposure of the liver to high concentrations of free fatty acids that cause progressive hyperinsulinaemia and tissue insulin resistance [11]. This mechanism is also described by Szczeklik-Kumala in a review on the treatment of diabetes among obese patients. Moreover, attention is paid to higher risk of type 2 diabetes among individuals with android obesity compared to those with gynoid obesity [38]. The present study revealed that $92.9 \%$ of the students thought that body weight was indeed a risk factor for the disease. A relationship between android obesity and increased risk of diabetes was indicated only by $18.5 \%$ of the examined secondary school students.

According to the recommendations of the Polish Diabetes Association, diabetes patients should undergo screening examinations for ischaemic heart disease (IHD). The guidelines of the European Society of Cardiology indicate that each patients with diabetes should be suspected of having IHD and the other way around: each patient with cardiovascular diseases should be suspected of having diabetes [41]. Cardiovascular diseases may therefore be classified both as a risk factor and a complication of diabetes. The present study shows that $53.2 \%$ of the students stated that cardiovascular diseases were risk factors and $60.7 \%$ believed them to be consequences of diabetes. Different outcomes were presented by Ślusarska et al., where $93.27 \%$ of the respondents indicated cardiovascular diseases as complications of type 2 diabetes [37]. In the meta-analysis on insulin resistance in the context of concomitant hypertension (HT), Jasik et al. demonstrated that, in most cases, HT precedes type 2 diabetes. The authors elucidate a relationship between primary HT and later development of diabetes with the impaired receptor signalling pathway for insulin, reduced blood flow and, in consequence, abnormal flow of glucose and insulin to peripheral tissues [17]. In the present study, $56 \%$ of the students indicated HT as a risk factor for type 2 diabetes. Another disease entity that is linked with type 2 diabetes is PCOS. Diabetes develops in $4-10 \%$ of women with this condition. Janeczek et al. demonstrated that $12.81 \%$ of the students indicated PCOS as a risk factor for type 2 diabetes [16]. The present study yielded different results as only $4.8 \%$ of the secondary school students decided that this answer was correct.

Glucocorticosteroids (GCS) are the most common drugs in the treatment of autoimmune diseases. Long-term use of these medications may lead to carbohydrate metabolism disorders, including type 2 diabetes. However, the risk mainly depends on therapy duration and dose of these drugs [25, 28]. In the present study, $74,0 \%$ of the students indicated long-term GCS treatment as a risk factor for type 2 diabetes. This results are confirmed by Dabrowski and Majdan, who found a 1.4 - 1.5-fold greater risk of diabetes in patients treated with GCS compared with the healthy population [4].

According to the recommendations of the Polish Gynaecological Society, women with a history of gestational diabetes with normal blood sugar levels in the puerperium should be tested for glucose tolerance after 2 months. If the results are normal, tests should be repeated once every three years as part of type 2 diabetes prophylaxis [42]. The present study indicates that $60 \%$ of the students believe gestational diabetes to be a risk factor for type 2 diabetes. The study on genetic and clinical risk factors of diabetes mellitus, conducted by Kwak et al., reveals that the majority of women with a history of gestational diabetes are also diagnosed with type 2 diabetes in early postpartum 
period and later in life [24]. Neonatal birth weight is also significant in the context of an increased risk of developing the disease. In the study of Mazur et al., it was demonstrated that the relationship between birth weight over $4 \mathrm{~kg}$ and later development of diabetes was significant [26]. In the present study, $26.3 \%$ of secondary school students indicated this relationship.

Eating habits are crucial factors involved in the pathogenesis of type 2 diabetes. The present study demonstrates that $92.4 \%$ of the students concur with this statement. Different results have been presented by Seń et al. They evaluated behaviours and knowledge about nutrition among university students in Wroclaw, Poland. The authors showed that $74 \%$ of the students of the Academy of Medicine, $58 \%$ of the students of Wroclaw University of Environmental and Life Sciences and $57 \%$ of the students of Wroclaw University of Science and Technology stated that diabetes mellitus was a consequence of wrong eating habits [36]. In the present study, $27.6 \%$ of the students indicated that excessive energy intake was a cause of increased risk of diabetes. Przybylska et al. demonstrated a relationship between positive energy balance that leads to overweight and obesity and, in consequence, to diabetes [30]. In the present study, $27.6 \%$ of the students indicated that intake of excessively calorific foods was one of the risk factors. Another factor conductive to the disease is excessive share of simple sugars in daily diet [20]. The present study shows that $92.6 \%$ of the students indicated excessive sugar intake as a significant factor that might speed up the development of diabetes. Low physical activity is another modifiable factor affecting the development of type 2 diabetes. In this study, $85.7 \%$ of the respondents agreed with this statement. Noczyńska et al. report different results: $55.7 \%$ of the respondents indicated sports as a factor that may lower the risk of the disease [27].

In the study of Dabska and Żotnierczuk-Kieliszek, $84.0 \%$ of the respondents stated that neuropathies manifesting with numbness and tingling were complications of type 2 diabetes [6]. The present study yielded different results. Only $12.2 \%$ of the students responded that neuropathies were a complication of diabetes, while $57.9 \%$ indicated diabetic foot syndrome as a complication of the disease. It was also found that $37.5 \%$ of the students indicated renal diseases as a possible complication of type 2 diabetes. Different results were obtained by Roomizadeh et al. who evaluated the knowledge about risk factors of kidney diseases. Only $12.7 \%$ of the respondents indicated diabetes mellitus as a risk factor [31]. Depression, as a real complication of diabetes, was indicated by $19.3 \%$ of the students, while Dabska et al. observed $55 \%$ and $61 \%$ of responses that diabetes carried emotional complications and required support of the family and friends [5].

The analysis of the present study demonstrated that $60.7 \%$ of the students indicated cardiovascular diseases as a serious complication of diabetes mellitus. Similar outcomes have been presented by Ying $X u$ et al., who evaluated the knowledge of Chinese students about diabetes [43]. The present study shows that $21.3 \%$ of the students indicated recurrent infections as possible complications of diabetes. Khan et al. reported similar results from a study on the knowledge of students about diabetes: $29 \%$ of the respondents pointed to these complications [19]. The present study shows that the most numerous group of the respondents were those with an average level of knowledge, i.e. those who provided $40-70 \%$ of correct answers (89.6\%). Kocka and Dziedzic [21] obtained different results: the average level of knowledge was noted in only $22.4 \%$ of the students, who provided $50-75 \%$ of correct answers, whilst most of the respondents were characterised by a low level of knowledge (74.3\%) and provided less than $50 \%$ of correct answers.

The limitation of the study is the regional nature of the study. Therefore, the authors recommend caution in interpreting the results in relation to the population.

\section{CONCLUSIONS}

1. The knowledge on risk factors for type 2 diabetes mellitus among secondary school students was varied. The most numerous group was characterized by an average level of knowledge.

2. There were no statistically significant differences between the percentage of correct answers provided by girls and boys.

3. There were statistically significant differences between the percentage of correct answers provided by first-, second- and third-grade students.

4. Our research shows that educational activities should be undertaken, especially about modifiable risk factors for type 2 diabetes.

\section{Conflict of interest}

The authors declare no conflict of interest

\section{REFERENCES}

1. American Diabetes Association: Standards of Medical Care in Diabetes - 2018. Diabetes Care 2018;41(Suppl. 1): S1-S159.

2. Cichosz G, Czeczot H. Kwasy tłuszczowe izomerii trans w diecie człowieka. Bromat. Chem Toksykol 2012; XLV (2):181-190 (in Polish).

3. Czech A.: Kontrowersja miedzy niechęcią stosowania profilaktyki cukrzycy typu 2 a dowodem jej dużej skuteczności w praktyce [Controversy between the 
inertia of the diabetes mellitus type 2 prophylactics and the evidence of its high efficacy in practice]. Med Metabol 2014;XVIII (4); 52-62 (in Polish).

4. Dąrowski P., Majdan M.: Zaburzenia tolerancji węglowodanowej w trakcie leczenia glikokortykosteroidami $\mathrm{u}$ chorych na zapalne schorzenia układu ruchu - na podstawie analizy danych z piśmiennictwa oraz wyników badań własnych [Glucose tolerance disorders during treatment with glucocorticoids in patients with inflammatory diseases of the musculoskeletal system - based on the analysis of data from the literature and own research results]. Postepy Hig Med Dosw 2017;(71);307-314 (in Polish).

5. Dąbska O., Pawlikowska-Łagód K., Firlej E., Wołoszynek E.: Postawy studentów wybranych szkół wyższych Polski wschodniej wobec cukrzycy [Attitudes of students of selected universities of Eastern Poland towards diabetes]. Journal of Education, Health and Sport. 2016;6(12):452-464 (in Polish).

6. Dąbska O., Żolnierczuk-Kieliszek D.: Poziom wiedzy na temat cukrzycy - badanie ankietowe studentów wybranych szkół wyższych z Lublina [The Level of Knowledge About Diabetes: Survey Based on the Group of Students from Selected Universities in Lublin]. Pielęg Zdr Publ 2016;6(4):285-293 (in Polish).

7. Delahanty LM, Pan Q, Jablonski K.A et al:: Effects of Weight Loss, Weight Cycling, and Weight Loss Maintenance on Diabetes Incidence and Change in Cardiometabolic Traits in the Diabetes Prevention Program. Diabetes Care 2014;37:2738-275.

8. Gibała M, Janowski G.: Wpływ stylu życia na zapobieganie oraz przebieg cukrzycy. Piel Zdr Publ 2016;6(1):63-6 (in Polish).

9. Global, regional, and national comparative risk assessment of 84 behavioural, environmental and occupational, and metabolic risks or clusters of risks, 1990-2016: a systematic analysis for the Global Burden of Disease Study 2016. Lancet 2017;390:1345-422.

10. Grams J, Garvey WT, Weight Loss and the Prevention and Treatment of Type 2 Diabetes Using Lifestyle Therapy, Pharmacotherapy, and Bariatric Surgery: Mechanisms of Action. Curr Obes Rep 2015;4(2):287302.

11. Grzeszczak W. Czy można zapobiegać rozwojowi cukrzycy typu 2 - co nowego opublikowano na ten temat na początku 2015 roku? [Is it possible to prevent the development of diabetes type 2 - what new they published to this subject at the beginning of 2015?]. Choroby Serca i Naczyń 2015;12(4):223-232 (in Polish).

12.Gür-Onacik S. Żbikowska A, Kowalska M. Źródła izomerów trans kwasów tłuszczowych na polskim rynku. Probl Hig Epidemiol 2014;95(1):120-124 (in Polish).

13. Gwiazda E.: Choroby cywilizacyjne XXI wieku profilaktyka, leczenie, edukacja [Civilization diseases of the 21st century - prevention, treatment, education] Terapia 2013;6(2);73-79 (in Polish).

14. International Diabetes Federation: Diabetes Atlas. Eight Edition 2017. 2

15. International Diabetes Federation: Diabetes Atlas. Ninth Edition 2019. 142
16.Janeczek I., Machaj M., Panczyk M., Sienkiewicz Z., Gotlib J.: Ocena poziomu wiedzy studentów ocena poziomu wiedzy studentów pielęgniarstwa [Assessment of nursing students' knowledge about type 2 diabetes mellitus]. Pielęgn Pol 2017;2(64):209-219 (in Polish).

17. Jasik M., Poradzka A., Fiedor P., Karnafel W.: Insulinooporność a nadciśnienie tętnicze [Insulin resistance and hypertension]. Med Metabol 2013; XVII (3): 62-67 (in Polish).

18. Kara I, Zysnarska M, Adamek R i wsp. Palenie tytoniu, alkohol i aktywność fizyczna wśród pacjentów z cukrzycą typu 2. Przegl Lek 2012;69(10): 944-946 (in Polish).

19. Khan N., Gomathi K.G., Syed Shehnaz S.I., Muttappallymyalil J.: Diabetes Mellitus-Related Knowledge among University Students in Ajman, United Arab Emirates. Clinical and Basic Research 2012;12:306-314.

20.Kłosiewicz-Latoszek L., Cybulska B.: Cukier a ryzyko otyłości, cukrzycy i chorób sercowonaczyniowych [Sugar and health hazard of obesity, diabetes mellitus and cardiovascular diseases]. Probl Hig Epidemiol 2011;92(2):181-186 (in Polish).

21. Kocka K., Dziedzic U.: Wiedza młodzieży licealnej na temat czynników ryzyka cukrzycy typu 2 [Knowledge of secondary school students on risk factors for type 2 diabetes]. Med Og Nauki Zdr 2013;19(3):255-261 (in Polish).

22.Kotlewska J, Jeznach-Steinhagen A, CzerwonogrodzkaSenczyna A. Związek między spożyciem wybranych płynów a ryzykiem zachorowania na cukrzycę. Pol Med J 2015; XXXVIII (224):119-122 (in Polish).

23. Kurpas D, Kern J.B, Jacquet J.P, Randall-Smith J, Mroczek B.: Programy promocji zdrowia i profilaktyki chorób - przykłady z Europy i USA. Fam Med \& Prim Care Review 2015;17(2): 152-156 (in Polish).

24.Kwak S.H., Choi S.H., Jung H.S. et al.: Clinical and Genetic Risk Factors for Type 2 Diabetes at Early or Late Post Partum After Gestational Diabetes Mellitus. J Clin Endocrinol Metab 2013;98 (4): E744-E752.

25.Lum-Namirowska L., Schlaffke J., ZozulińskaZiólkiewicz D.: Cukrzyca w wieku starczym - trudności i możliwości [Diabetes in the elderly - the difficulties and capabilities]. Geriatria 2016;10:171-178 (in Polish).

26.Mazur A., Klimek K., Małecka-Tendera E.: Czynniki ryzyka występowania otyłości u dzieci szkolnych w województwie podkarpackim [Risk factors of obesity in school children from Podkarpatian Region]. Endokrynologia, Otyłość i Zaburzenia Przemiany Materii 2011;7(3):157-166 (in Polish).

27. Noczyńska A., Pirogowicz I., Szykowna I.: Ocena stanu wiedzy o cukrzycy u pacjentów niechorujących na cukrzycę leczonych w różnych oddziałach Miedziowego Centrum Zdrowia [Evaluation of the state of knowledge about diabetes in non-diabetic patients treated in various departments of the Copper Health Center]. Med Metabol 2009; XIII (2):64-68 (in Polish).

28.Pisarczyk-Wiza D., Zozulińska-Ziótkiewicz D.: Glikokortykosteroidy a zaburzenia metabolizmu glukozy [Glucocortycosteroids and disturbances of glucose metabolism] Diabet Klin 2015;4(3):110-116 (in Polish). 
29. Polskie Towarzystwo Diabetologiczne. Diabetologia Praktyczna. Zalecenia kliniczne dotyczące postępowania u chorych na cukrzycę 2018. Stanowisko Polskiego Towarzystwa Diabetologicznego [Polish Diabetes Society. Practical Diabetology. Clinical recommendations for the management of patients with diabetes 2018. Position of the Polish Diabetes Association]. 2018;4(1): 6 (in Polish).

30. Przybylska D., Kurowska M., Przybylski P.: Otyłość i nadwaga w populacji rozwojowej [Obesity and overweight in the adolescent population]. Hygeia Public Health 2012;47(1):28-35 (in Polish).

31. Roomizadeh P., Taheri D., Abedini A.: Limited knowledge of chronic kidney disease and its main risk factors among Iranian community: an appeal for promoting national public health education programs. International Journal of Health Policy and Management 2014;2(4):161-166.

32.Rybarczyk-Szwajkowska A.: Awareness of civilization diseases threat amongst students - international comparative research. Journal of Health Policy, Insurance and Management - Polityka Zdrowotna 2013;XIII/III:119-132.

33. Saryusz-Wolska M., Czupryniak L.: „Porażki” wielkich badań w diabetologii sukcesem medycyny prewencyjnej [,Failures“ of great research in diabetology with the success of preventive medicine]. Diabetologia na co Dzień 2010; 2(19):31-41 (in Polish).

34. Schlaffke J, Lachowicz D, Araszkiewicz A, Zozulińska -Ziółkiewicz D.: Ocena nawyków spożycia alkoholu wśród osób $\mathrm{z}$ cukrzycą. Forum Zab Metabol 2012;3(4):131-139 (in Polish).

35. Schwingshackl L, Schlesinger S, Devleesschauwer B et al. Conference on Diet, nutrition and the changing face of cancer survivorship. International Nutrition Student Research Championship 2017 Programme. Generating the evidence for risk reduction: a contribution to the future of food-based dietary guidelines. Proceedings of the Nutrition Society 2018;1-13. doi:10.1017/ S0029665118000125.

36.Seń M., Zacharczuk A., Lintowska A.: Zachowania żywieniowe studentów wybranych uczelni wrocławskich a wiedza na temat skutków zdrowotnych nieprawidłowego żywienia. Piel Zdr Publ 2012;2(2):113-123.

37. Ślusarska B., Kulik T.B., Piasecka H., Pacian A.: Wiedza i zachowania zdrowotne studentów medycyny w zakresie czynników ryzyka sercowo-naczyniowego [Knowledge and health behaviour of medical students in the field of cardiovascular risk factors]. Nauk Zdr 2012;18(1):19-26 (in Polish).

38. Szczeklik Kumala Z.: Leczenie cukrzycy u osób otyłych [Treatment of diabetes in obese people]. Świat Medycyny i Farmacji 2010;28-39 (in Polish).

39. Tatoń J.: Kontrast „,palących” potrzeb i opieszałości reformatorskich działań w medycznej i społecznej opiece diabetologiczne. Jak długo jeszcze? [A contrast between the ,burning“ needs and the sluggishness of reforming activities in medical and social diabetes care. How much longer]. Med Metabol 2012; XVIII (4): 9-12 (in Polish).

40. Walicka M., Chomiuk T., Filipiak K.J., Mamcarz A., Olszanecka-Glinianowicz M., Wożakowska-Kapłon B., Wyleżot M., Franek E.: Zapobieganie rozwojowi cukrzycy typu 2. Stanowisko grupy ekspertów wsparte przez Sekcję Farmakoterapii Sercowo-Naczyniowej Polskiego Towarzystwa Kardiologicznego [Type 2 diabetes prevention. Experts ${ }^{6}$ Group position paper endorsed by the Polish Cardiac Society Working Group on Cardiovascular Pharmacotherapy]. Kardiol Pol 2015;73,10: 949-957 (in Polish).

41. Wetnecki M., Lapiak-Pasiorowska E., Mamcarz A.: Współistnienie cukrzycy i przewlekłej choroby niedokrwiennej serca - implikacje terapeutyczne [Coexistence of diabetes and chronic ischemic heart disease - therapeutic implications]. Kardiologia po Dyplomie 2013;(12):7-15 (in Polish).

42. Wender-Ożegowska E., Bomba-Opoń D., Celewicz Z. et al.: Standardy Polskiego Towarzystwa Ginekologicznego postępowania u kobiet z cukrzycą [Standards of the Polish Society for Gynecological Behavior in Women with Diabetes]. Ginekol Pol 2011;82:474-479 (in Polish).

43. Xu Y., Zhang D., Liu Z., Guo Y., Yang Yi.: Self-reported knowledge on diabetes and its related factors among Chinese college students: a cross-sectional study. BMJ Open 2016;6:e011963.

44. Stelmach $M$. Rola aktywności fizycznej w profilaktyce otyłości oraz innych przewlekłych chorób niezakaźnych. Człowiek i Zdrowie 2010; I (IV): 50-58 (in Polish).

45. Uruska A, Araszkiewicz A, Uruski P, Naskret D, Zozulińska-Ziótkiewicz D.: Palenie tytoniu zwiększa insulinooporność u chorych na cukrzycę typu 1. Wyniki badania Poznan Prospective Study (PoProStu). Diabet Prakt. 2018;4(2): 130-136 (in Polish).

46. Wiciński M, Ciemna K, Soroko A.: Leki czy dieta? Wpływ zdrowego żywienia w profilaktyce wybranych jednostek chorobowych. Przegląd badań klinicznych (według EBM). [W]: Znaczenie racjonalnego żywienia w edukacji zdrowotnej, red. A. Wolska-Adamczyk, WSIiZ, Warszawa 2015;151-161 (in Polish).

47. Wu $Y$, Ding $Y$, Tanaka $Y$, Zhang $W$ : Risk Factors Contributing to Type 2 Diabetes and Recent Advances in the Treatment and Prevention. Int $\mathrm{J}$ Med Sci 2014;11(11):1185 -1200

48.Zegan M, Michota-Katulska E, Lewandowska M, Boniecka I.: Rola podejmowanej aktywności fizycznej w profilaktyce oraz wspomaganiu leczenia otyłości oraz cukrzycy typu 2. Med Rodz 2017;20(4):273-278 (in Polish).

Received: 16.07 .2020

Accepted: 09.10.2020 